\title{
THE IMPORTANCE OF PERIOPERATIVE PROPHYLAXIS WITH CEFUROXIME OR CEFTRIAXONE IN THE SURGICAL SITE INFECTIONS PREVENTION AFTER CRANIAL AND SPINAL NEUROSURGICAL PROCEDURES
}

\author{
Aleksandra Dimovska-Gavrilovska ${ }^{1}$, Aleksandar Chaparoski ${ }^{1}$, Andreja Gavrilovski ${ }^{2}, Z_{\text {Zvonko Milenkovikj }}^{3}$ \\ ${ }^{1}$ University Clinic for Neurosurgery Vodnjanska 17 1000. Skopje \\ ${ }^{2}$ University Clinic for Traumatology Vodnjanska 17 1000. Skopje \\ ${ }^{3}$ University Clinic for Infectious Diseases Vodnjanska 17 1000. Skopje
}

Corresponding author: Ass. D-r Aleksandra Dimovska Gavrilovska Dr. Med., Medical Faculty, University "St. Cyril and Metodius" Skopje, University Clinic for Neurosurgery Vodnjanska 17, 1000, Skopje, Republic of Macedonia

\begin{abstract}
Introduction

Surgical site infections pose a significant problem in the treatment of neurosurgical procedures, regardless of the application of perioperative prophylaxis with systemic antibiotics. The infection rate in these procedures ranges from less than $1 \%$ to above $15 \%$. Different antibiotics and administration regimes have been used in the perioperative prophylaxis so far, and there are numerous comparative studies regarding their efficiency, however, it is generally indicated that the choice thereof should be based on information and local specifics connected to the most probable bacterial causers, which would possibly contaminate the surgical site and cause infection, and moreover, the mandatory compliance with the principles of providing adequate concentration of the drug at the time of the anticipated contamination.
\end{abstract}

\section{Objective}

Comparing the protective effect of two perioperative prophylactic antibiotic regimes using cefuroxime (second generation cephalosporin) and ceftriaxone (third generation cephalosporin) in the prevention of postoperative surgical site infections after elective and urgent cranial and spinal neurosurgical procedures at the University Clinic for Neurosurgery in Skopje in the period of the first three months of 2016.

\section{Design of the study}

Prospective randomized comparative study.

\section{Outcome measures}

Establishing the clinical outcome represented as prevalence of superficial and deep incision and organ/space postoperative surgical site infections.

\section{Material and method}

We analyzed prospectively 40 patients who received parenteral antibiotic prophylaxis with two antibiotic regimes one hour before the routine neurosurgical cranial and spinal surgical procedures; the patients were randomized in two groups, according to the order of admission and participation in the study, alternately, non-selectively, those persons who fulfilled inclusion criteria were placed in one of the two programmed regimes with cefuroxime in the first, and cefotaxime in the second compared group. All relevant demographic and perioperative patient data were analyzed for both comparative groups, especially the factors known to cause disposition (predisposition) to infections. The prevalence of postoperative infections was evaluated as the primary outcome 
in both comparative groups, while the secondary outcome was the postoperative infection rate after cranial and spinal neurosurgical procedures at the Neurosurgical clinic in Skopje (having in consideration that so far no data have been published in this context), as well as the prevalence of the risk factors for occurrence of postoperative infections, pre-surgically in patients undergoing neurosurgical interventions locally in the Republic of Macedonia.

\section{Results}

A total of three cases of postoperative infections were registered, two of which classified as superficial incisional, while one case organ/space infection - meningitis (elective intervention) without etiological confirmation. Both comparative groups were statistically similar, without any statistically significant differences in the basic demographic and perioperative characteristics, especially in relation to the incidence of the factors, which, regardless of the antibiotic prophylaxis, show predisposition to postoperative infections. All three cases with infections were registered in the group of persons who received prophylaxis with ceftriaxone preoperatively, with isolated etiological S. aureus agent (elective intervention) in one of them, and methicillin resistant staphylococcus aureus (MRSA) in another (urgent intervention) with superficial incisional SSI. There was no case of SSI in the group of patients who received cefuroxime before surgery.

\section{Conclusion}

Administration of parenteral antibiotics before surgery reduces the incidence of postoperative infections after neurosurgical procedures, especially in cases with increased risk factors for SSI, such as ACA score of $\geq 2 / 3$, the duration of the surgical intervention $\geq 4$ hours, contaminated wound and comorbidities. Perioperative antibiotic prophylaxis should be directed to better coverage of the S.aureus arrays.

Key words: Surgical site infections, Neurosurgery, Antibiotic prophylaxis, Cefuroxime, Ceftriaxone

\section{INTRODUCTION}

Surgical site infections (SSI) are most common infections associated with the healthcare of surgically treated patients [1]. The incidence of SSI varies between $1 \%$ and $17 \%$, depending on the definition of infection, the duration of postoperative monitoring, the institution and the type of performed surgical procedure $[2,3,4,5,6]$. In addition to the notable advancement and improvements of the surgical practice and the infections control techniques, SSI continue to be burden for the patients and healthcare services in context of morbidity, mortality and expenses, and are still the main threat to the wellbeing of postsurgical patients [2]. Having in consideration that the complete eradication of SSI is not practically possible, most of them are potentially preventable with the help of efficient strategic prevention approaches [7]. With careful monitoring, a significant reduction of SSI incidence is possible [8], whereas in hospitals with strict surveillance and infection control programs, within 4-6 years, the reduction is $19-41 \%[9,2,10]$. The SSI incidence has been determined by numerous exogenous and endogenous factors and it depends on the characteristics of the patient, the surgical intervention/procedure, the staff and hospital [11]. Thus, one of the key components of any SSI prevention strategy is the multidisciplinary approach and inclusion of all relevant persons as a team in the improvement process. As a result of the implementation of a comprehensive prevention program, one study registered a clear trend of the SSI rate, from $6.21 \%$ in 2008 to $2.28 \%$ in 2013 [2].

The SSI incidence in patients after neurosurgical intervention ranges between $1.25 \%$ and $17 \%$ in conditions of prophylactic administration of antibiotics, and $0.3 \%$ to $3.0 \%$ in absence of antibiotic prophylaxis $[2,12,4,13,14]$. The suggested allowed rank of annual SSI incidence is the marginal value of less than 5\% [15].

SSI are associated with increased morbidity, mortality, and increased hospitalization costs, prolonged hospitalization on an average of 4 to 7 days and twice the risk of fatal outcome, twice increased probability for ICU treatment, and five times greater chance of post-discharge hospitalization $[16,17,18]$. Furthermore, due to the prolongation of the illness and the hospitalization, SSI patients suffer emotionally and physically, which results in prolonged absence from their usual activities, social life and family disruptions due to the deterioration in their status and the insecurity related to their health related problems [16]. 
In neurosurgery, SSI's are important due to their clinical significance, association with negative prognosis, high mortality and great number of sequels in surviving persons. These infections may be superficial infections of the wound, shunt infections or ventricular shunts, intra-parenchymal abscesses and meningitis [19]. In neurosurgery, most of the procedures are considered "frequent" compared to manipulations in sterile tissues [16].

Surgical site infections (SSI) are considered important complications of surgical interventions and are associated with significant morbidity and mortality. They entail serious consequences for the patients and high financial costs [20]. SSI result in pain, discomfort, prolonged hospitalization and permanent disability, which are all underlying reasons for increased costs [21]. According to different studies, SSI result in increased hospitalization of patients, around 10 days and additional costs of approximately USD 2.000 [22], whereas, each SSI results in additional postoperative hospital stay of 7.3 days and extraordinary costs of USD 3.152 [12], while, compared to the SSI which are limited only to the site of incision, deep SSI which involve organs or space are associated with even longer hospitalizations and greater costs $[23,12]$.

Global achievements in enhancement of air-conditioning of ORs, sterilization methods, barriers, surgical techniques, as well as the application of antimicrobial prophylaxis have provided for improved infection control, however, it is suggested that complete eradication of postoperative infections in patients is not possible. This conclusion is partially due to the incidence and increase of microorganisms resistant to the usually applied antimicrobial agents, and also to the increased number of elderly who, in addition to their age, bear other risk factors of chronic and immunocompromising illnesses and primary disability [21,12].

Even though SSI's are rare in neurosurgical patients, they result in serious consequences, especially in craniotomies. Knowledge of the risks of infection and identification of patients with high risk provide for the opportunity for implementation and instructed delivery/undertaking specific preventive institutional measures for certain patients. SSI rate indicators are one of the ways to evaluate the quality and effectiveness of hospital care and treatment. The treatment of patients may be improved by knowing the risks and preventive methods.

The key objective of the study was the attempt to evaluate the protective effect of perioperative antimicrobial prophylaxis in context of
SSI prevention using two different regimes: With cefuroxime and ceftriaxone, which according to the literature $[24,25,26,27,28,29,30]$ and the experience with their use at the Neurosurgical clinic in Skopje, considering that so far there are no published data in this regard in RM, to provide for initial insight in the incidence of SSI after neurosurgical procedures, and identify patients with increased risk of SSI after performed neurosurgical interventions in the Republic of Macedonia.

\section{MATERIAL AND METHOD}

The protocol of conducting the study is not different compared to the standardized which has been so far routinely used in patients undergoing neurosurgical intervention in our institution, with mandatory perioperative antibiotic prophylaxis, however, in the interest of this study, randomized (according to the order of coming of the patients, alternately, by administration of cefuroxime or ceftriaxone, within 60 minutes before initial incision. All patients underwent standardized set of procedures as usual, when admitted, during and after the neurosurgical intervention, during their hospital stay, when discharged and during follow-ups.

Both antibiotics (cefuroxime and ceftriaxone) administered parenterally (intravenous) in determined dosage and at the given time intervals before starting the surgery, calculated according to the time of first incision, provide a specter of effect which covers the most frequent etiological agents of postsurgical infections arising from colonization of skin and external barriers of the patient, and in the surgical site and the place of performing the surgical intervention reach concentrations sufficiently high and above MIC during the whole duration of the intervention, which is basic/key precondition for efficient perioperative antibiotic prophylaxis.

The study involves all patients undergoing cranial and spinal neurosurgical procedures, without age limitation, with BMI (calculated according to the anamnestic data about height and weight) in normal range of 18.5 to 25 (WHO), hospitalized two or less than two days before surgery (inclusion criteria), while the exclusion criteria for participation in the study were psychosomatic developmental disability, allergy to penicillin, BMI outside the above mentioned range, long-term therapy with corticosteroids, cytostatics and antibiotics, as well as previous in-patient treatment of one months as a result of another illness. 
The study was designed as prospective randomized controlled study, implemented at the University Clinic for Neurosurgery in Skopje, during 2016, and involved 40 patients according to the order of their admission at the Clinic, which were non-selectively, alternately, randomized in two groups. In one group, by random selection according to the time of admission of the patient before surgery (within 60 minutes before incision) intravenously was administered a vile of Cefuroxime $1.5 \mathrm{~g}$ (intraoperatively, the dosage was repeated in case of prolonged surgery, lasting longer that two half-lives of the antibiotic, i.e. every 3 hours per $750 \mathrm{mg}$, or in cases of severe hemorrhage, more than 1.51) and the other group, in the same time interval and under the same principles (inside 60 minutes before incision) instead of cefuroxime, were treated with intravenous vile of Ceftriaxone $2.0 \mathrm{~g}$. The persons allergic to penicillin were preoperatively treated with vancomycin, and they were not included in the study. After the surgery, the patients were carefully monitored and analyzed for signs of infections in the following 30 days and 6 weeks, and afterwards, three months for sign of colonization.

All initial preoperative procedures were performed according to the established routine practice (clinical examination, complete laboratory-biochemical analyses) RTG, CT, MRI, and all other necessary specific diagnostic procedures for the individual patient. All symptoms and signs (local and systemic) were postoperatively carefully monitored for infection, both during the period of hospitalization and the follow-ups after discharging the patient, after one and three months. Both the incidence of local symptoms and signs (redness, swelling, discharge, pus, non-healing up and pain) and systemic ones (high temperature, deterioration of general health, headaches, vomiting, disorders of consciousness, neurological deficits).

In case of symptoms and signs of infection, we immediately conducted the following targeted examinations: wound smear, blood culture and other microbiological investigations, full bloodwork with peripheral smear and sedimentation, CRP, other laboratory and biochemical and hepatic examination, urine, urea, glycaemia, CT, MRI, as well as all other necessary specific analyses, depending on localization, the type of infection and its extensiveness.

During 2016, 40 patients who underwent neurosurgical intervention at the Neurosurgical clinic in Skopje were analyzed. Neurosurgical cranial procedures covered by the study were craniectomy, craniotomy, cranioplastic surgery and burr hole, and spinal procedures such as laminectomy, discectomy, foraminotomy, cist resection, and reparation of myelomeningocele. Patients who underwent one of the above mentioned neurosurgical procedures, based on inclusion criteria, were selected and monitored postoperatively for signs of SSI. The study involved patients at the age from 0-99 who underwent selective or urgent intervention, who survived at least 7 days after the surgical intervention. Patients with implanted primary liquor shunt, endoscopic surgical intervention, such as ventriculostomy in the third ventricle, patients highly suspected for infection of the central nervous system before the procedure, including subdural empyema, cerebral abscess, or infectious disease, such as tuberculosis, toxoplasmosis or cryptococcosis infection, patients with contaminated wound, and those who died during 48 hours after surgery were not included in the study (exclusion criteria). The monitoring period of the patients was at least 30 days postoperatively or until the fatal outcome in persons who survived less than 30 days, if the patient had been still hospitalized. Discharged patients were again examined at the Neurosurgical clinic 30 days post-surgery, in order to determine any sign of postoperative SSI. Data were prospectively collected for the patients' age, sex, data of hospitalization, ACA classification of preoperative physical status, antibiotic prophylaxis, and as regards the surgical procedure, data about the date of surgery, reason for the surgical intervention (tumor, vascular or functional trauma), wound classification (clean, clean-contaminated, contaminated and contaminated-infected), duration/length of surgery, type of intervention, implant, type of drainage and number of performed procedure. The classification of surgical wounds was adjusted to the specifics of neurosurgery, according to which, contaminated-infected wounds include brain abscess, subdural empyema and osteitis in the cases with already present sepsis; contaminated included patients with traumatic injury with open cranial fractures or lacerations of the scalp older than 4 hours; clean-contaminated procedures involved interventions with tightening/entering paranasal sinuses or mastoids, repair of cranium based fractures, or in cases of protrusion/interruption of aseptic surgical techniques; clean surgical interventions include most of the planned procedure. The duration of the prophylactic antibiotic treatment was noted. Early subsequent operative interventions 
and wound infections (type, date and etiological agent) were noted in the postoperative period. Early subsequent operative interventions included urgent operative interventions/procedures, usually performed in the first 24 to 48 hours after the primary surgical procedure due to postoperative hematoma. SSI were classified according to the instructions/guidelines of the contagious disease control center (CDC) and diagnoses are established by the surgeon. SSI classification covers the following: Scalp infection (purulent discharge from the site of the incision, isolated bacterium from a serous drainage, or clinical diagnosis by the neurosurgeon) bone (bone flap) osteitis (either surgical diagnosis of osteitis or increased temperature with local signs and discharge, and positive blood culture or indicated RTG); meningitis-ventriculitis (either coloration per gram and/or microorganism determined through myeloculture, or liquor pleocytosis with increased cerebrospinal fluid and/or reduced CSF glucose, associated with increased temperature and cervical rigidity, and antibiotic therapy prescribed by the clinician); cerebral abscess and empyema (either isolated microorganism from the brain tissue or subdural space, or surgical diagnosis for brain abscess, or temperature, deteriorated mental status and/or focal neurological deficit and indicated CT, with antibiotic treatment by a clinician). According to the CDC criteria, scalp wound infections are defined as superficial incision infections, while osteitis and meningitis and abscess/empyema as organ/space infections.

\section{RESULTS}

The research involved 40 respondents, half of which treated with antibiotic parenteral perioperative prophylaxis with cefuroxime $(\mathrm{C} 2)$ and half with ceftriaxone $(\mathrm{C} 3)$.

The average age of the respondents was $51.12 \pm 19.9$ years, the youngest, 3 years of age, and the oldest at the age of 81 (Table 1). The respondents who underwent treatment with perioperative prophylaxis with cefuroxime and ceftriaxone were not of significant age difference $(p=0.45)$. Patients treated pre-surgery with cefuroxime were significantly older $(53.55 \pm 14.1$ compared to $48.7 \pm 24.6$ ).

The distribution of patients in both groups according to age is presented in Table 2 , and it shows that patients from the group treated with cefuroxime were mostly at the age from 50 to 65 $(11 / 20)$, while patients from the group treated with ceftriaxone were mostly at the age of 66 years and older (6/20). However, these patients, compared to the patients who were treated with cefuroxime more often belonged to younger age groups, i.e. 5 patients at the age of 25 years, compared to only one patient from the group treated with cefuroxime (Fisher exact $p=0.26$ ).

The gender structure of the patients was represented by $25(62.5 \%)$ male patients and 15 (37.5\%) female patients (Table 3). The distribution of male and female respondents regarding the type of administered antibiotic perioperative prophylaxis was statistically insignificant $(\mathrm{p}=0.3)$.

Table 1.

\begin{tabular}{|c|c|c|c|c|}
\hline \multirow{2}{*}{ ANTIBIOTIC } & \multicolumn{3}{|c|}{ AGE (years) } & \multirow{2}{*}{ p-value } \\
\cline { 2 - 4 } & mean \pm SD & Std error & Min-max & \multirow{2}{*}{$\mathrm{T}=0.76$} \\
$\mathrm{P} 2$ & $53.55 \pm 14.1$ & 3.15 & $3-77$ & $3-81$ \\
\hline C3 & $48.7 \pm 24.6$ & 5.5 & $3-81$ & \\
\hline TOTAL & $51.12 \pm 19.9$ & 3.15 & $\mathrm{~ns}$ \\
\hline
\end{tabular}

C2 Cefuroxime, C3 - Ceftriaxone

$\mathrm{t}$ (Student $\mathrm{t}$ test)

Table 2.

\begin{tabular}{|c|c|c|c|c|c|c|c|}
\hline \multirow{2}{*}{ ANTIBIOTIC } & \multicolumn{6}{|c|}{ AGE GROUPS (years) } & \multirow{2}{*}{ TOTAL } \\
\hline & $\leq \mathbf{5}$ & $6-13$ & $14-25$ & $26-49$ & $50-65$ & $66 \geq$ & \\
\hline $\mathrm{C2}$ & & & $1(5.0 \%)$ & $5(25.0 \%)$ & $11(55.0 \%)$ & $3(15.0 \%)$ & 20 \\
\hline C3 & $1(5.0 \%)$ & $2(10.0 \%)$ & $2(10.0 \%)$ & $4(20.0 \%)$ & $5(25.0 \%)$ & $6(30.0 \%)$ & 20 \\
\hline TOTAL & $1(2.5 \%)$ & $2(5.0 \%)$ & $3(7.5 \%)$ & $9(22.5 \%$ & $16(40 \%)$ & $9(22.5 \%)$ & $40(100 \%)$ \\
\hline
\end{tabular}

C2 Cefuroxime, $\mathrm{C} 3$ - Ceftriaxone 
Table 3.

\begin{tabular}{|c|c|c|c|c|}
\hline \multirow{2}{*}{ GENDER } & \multirow{2}{*}{ TOTAL } & C2 & ANTIBIOTIC & \multirow{2}{*}{ p-value } \\
\cline { 3 - 4 } & & $11(55.0 \%)$ & $14(70.0 \%)$ & \multirow{2}{*}{$\begin{array}{c}\text { Chi-square }=0.96 \\
\mathrm{P}=0.3 \mathrm{~ns}\end{array}$} \\
\hline MEN & $25(62.5 \%)$ & $9(45.0 \%)$ & $6(30.0 \%)$ & 20 \\
\hline TOTAL & $15(37.5 \%)$ & 20 & 40 & \\
\hline
\end{tabular}

C2 Cefuroxime, $\mathrm{C} 3$ - Ceftriaxone

Table 4.

\begin{tabular}{|c|c|c|c|c|c|}
\hline VARIABLE & C2+C3-n(\%) & $\mathrm{C} 2-n(\%)$ & C3-n(\%) & SSI C3 & p-value* \\
\hline $\begin{array}{l}\text { Procedure } \\
\text { Cranial } \\
\text { Spinal } \\
\end{array}$ & $\begin{array}{c}22(55 \%) \\
18(45) \\
\end{array}$ & $\begin{array}{c}8(40 \%) \\
12(60 \%) \\
\end{array}$ & $\begin{array}{c}14(70 \%) \\
6(30 \%) \\
\end{array}$ & 3 & $\begin{array}{c}\text { Chi-square } \\
\quad=3.6 \\
\mathrm{P}=0.056\end{array}$ \\
\hline $\begin{array}{l}\text { Type of intervention } \\
\text { Elective } \\
\text { Urgent }\end{array}$ & $\begin{array}{l}30(75 \%) \\
10(25 \%)\end{array}$ & $\begin{array}{c}18(90 \%) \\
2(10 \%)\end{array}$ & $\begin{array}{c}12(60 \%) \\
8(40 \%)\end{array}$ & $\begin{array}{l}2 \\
1 \\
\end{array}$ & $\begin{array}{l}\text { Chi-square } \\
=1.8 \\
\mathrm{P}=0.028^{* *}\end{array}$ \\
\hline $\begin{array}{l}\text { Reason for intervention } \\
\text { Trauma } \\
\text { Vascular } \\
\text { Infective } \\
\text { Functional } \\
\text { Tumor } \\
\end{array}$ & $\begin{array}{c}3(7.5 \%) \\
5(12.5 \%) \\
1(2.5 \%) \\
17(42.5 \%) \\
14(35 \%) \\
\end{array}$ & $\begin{array}{c}1(5 \%) \\
1(5 \%) \\
11(55 \%) \\
7(35 \%) \\
\end{array}$ & $\begin{array}{l}2(10 \%) \\
4(20 \%) \\
1(5 \%) \\
6(30 \%) \\
7(35 \%) \\
\end{array}$ & $\begin{array}{l}1 \\
1 \\
1\end{array}$ & $\begin{array}{c}\text { Fisher exact } \\
\mathrm{P}=0.3\end{array}$ \\
\hline $\begin{array}{l}\text { ACA classification } \\
\text { ACA1 } \\
\text { ACA2 } \\
\text { ACA3 }\end{array}$ & $\begin{array}{c}12(30 \%) \\
17(42.5 \%) \\
11(27.5 \%) \\
\end{array}$ & $\begin{array}{c}4(20 \%) \\
11(55 \%) \\
5(25 \%) \\
\end{array}$ & $\begin{array}{l}8(40 \%) \\
6(30 \%) \\
6(30 \%) \\
\end{array}$ & $\begin{array}{l}1 \\
2 \\
\end{array}$ & $\begin{array}{c}\text { Fisher exact } \\
\mathrm{P}=0.27\end{array}$ \\
\hline $\begin{array}{l}\text { Duration of intervention } \\
\text { less than } 4 \text { hours } \\
\text { more than } 4 \text { hours }\end{array}$ & $\begin{array}{l}28(70 \%) \\
12(30 \%)\end{array}$ & $\begin{array}{c}12(60 \%) \\
8(40 \%) \\
\end{array}$ & $\begin{array}{c}16(80 \%) \\
4(20 \%)\end{array}$ & $\begin{array}{c}2 \\
1(6 h)\end{array}$ & $\begin{array}{c}\text { Chi square } \\
=1.9 \\
\mathrm{P}=0.17\end{array}$ \\
\hline $\begin{array}{l}\text { Type of wound } \\
\text { clean } \\
\text { Clean-contaminated } \\
\text { Contaminated }\end{array}$ & $\begin{array}{c}39(97.5 \%) \\
1(2.5 \%)\end{array}$ & $20(100 \%)$ & $\begin{array}{c}18(90 \%) \\
1(5 \%) \\
1(5 \%)\end{array}$ & $\begin{array}{l}1 \\
1 \\
1\end{array}$ & $\begin{array}{c}\text { Fisher exact } \\
\mathrm{P}=1.0\end{array}$ \\
\hline $\begin{array}{l}\text { Type of drainage } \\
\text { Without drainage } \\
\text { Early operative } \\
\text { Liquor }\end{array}$ & $\begin{array}{l}17(42.5 \%) \\
23(57.5 \%)\end{array}$ & $\begin{array}{c}11(55 \%) \\
9(45 \%)\end{array}$ & $\begin{array}{c}6(30 \%) \\
14(70 \%)\end{array}$ & & $\begin{array}{l}\text { Chi square } \\
=2.56 \\
\mathrm{P}=0.11\end{array}$ \\
\hline
\end{tabular}

C2 - Cefuroxime

C3- Ceftriaxone

- $\mathrm{C} 2$ compared to $\mathrm{C} 3$ (statistical significance)

SSI - surgical site infections

Table 5.

\begin{tabular}{|c|c|c|c|}
\hline \multirow{2}{*}{ VARIABLE } & \multicolumn{2}{|c|}{ DESCRIPTIVE STATISTICS (all 40 patients) } \\
\cline { 2 - 4 } & mean \pm SD & std. error & Min-max \\
\hline AGE (years) & $51.12 \pm 19.9$ & 3.15 & $3-81$ \\
\hline SURGERY (hours) & $3.25 \pm 1.67$ & 0.26 & $1-8$ \\
\hline STAY (DAYS) & $12.4 \pm 8.9$ & 1.4 & $2-45$ \\
\hline
\end{tabular}

Male patients were more often treated with ceftriaxone ( $70 \%$ as opposed to $30 \%)$, while female patients more often with cefuroxime ( $45 \%$ as opposed to $30 \%$ ).

The statistical analyses (Table 4) showed insignificant association of the type of perioperative antibiotic prophylaxis and the type of procedure $(p=0.056)$, reason for intervention $(p=0.3), A C A$ classification $(p=0.27)$, the duration of the intervention more or less than 4 hours $(p=0.17)$, the type of wound $(p=1.0)$ and the type of drainage $(\mathrm{p}=0.11)$, and significant association with the type of intervention $(\mathrm{p}=0.028)$. Perioperative prophylaxis with cefuroxime was significantly more fre- 
Table 6.

\begin{tabular}{|c|c|c|c|c|}
\hline \multirow{2}{*}{ ANTIBIOTIC } & \multicolumn{2}{|c|}{ DURATION OF SURGERY (HOURS) } & \multirow{2}{*}{ p-value } \\
\cline { 2 - 4 } & mean \pm SD & median & IQR & \multirow{2}{*}{$\mathrm{Z}=1.85$} \\
\hline C2 & $3.65 \pm 1.8$ & 3.25 & $2.5-4$ & $\mathrm{P}=0.06 \mathrm{~ns}$ \\
\hline C3 & $2.85 \pm 1.5$ & 2 & $2-3.75$ & \\
\hline
\end{tabular}

C2 Cefuroxime, C3 - Ceftriaxone

Z (Mann-Whitney test)

Table 7.

\begin{tabular}{|c|c|c|c|c|}
\hline \multirow{2}{*}{ ANTIBIOTIC } & \multicolumn{2}{|c|}{ POSTOPERATIVE HOSPITALIZATION (DAYS) } & \multirow{2}{*}{ p-value } \\
\cline { 2 - 4 } & mean \pm SD & median & $6-15.5$ & \multirow{2}{*}{$\mathrm{Z}=0.9$} \\
\hline C2 & $11.5 \pm 9.9$ & 8 & $6-18.5$ & $\mathrm{P}=0.3 \mathrm{~ns}$ \\
\hline C3 & $13.25 \pm 8.2$ & 12 & IQR \\
\hline
\end{tabular}

C2 Cefuroxime, C3 - Ceftriaxone

Z (Mann-Whitney test)

quently ordinated before elective interventions (90\% compared to $60 \%$ ), i.e. ceftriaxone more frequent with urgent interventions ( $40 \%$ compared to $10 \%)$.

Our research results showed that the type of perioperative antibiotic prophylaxis did not significantly affect the length of surgery expressed in hours $(p=0.06)$. Patients treated with cefuroxime presented with insignificantly longer duration of surgery compared with patients treated with ceftriaxone. The average duration of the intervention in the group of patients treated with cefuroxime was $3.65 \pm 1.8$ hours, compared to $2.85 \pm 1.5$ hours, which was the average duration of the intervention in the group of patients treated with ceftriaxone (Table 5 and Table 6).

Hospital stay which was an average of $12.4 \pm 8.9$ (from 2 to 45 days) for all 40 patients (Table 5) post-surgery, was insignificantly different (Table 7) among patients who were treated with cefuroxime and ceftriaxone $(\mathrm{p}=0.3)$. Postoperative hospitalization was an average of $11.5 \pm 9.9$ and $13.25 \pm 8.2$ in the groups treated with cefuroxime and ceftriaxone, respectively.

Postoperative infection was registered in 3 patients (Table 4) who underwent cranial neurosurgical procedure, and treated with antibiotic prophylaxis with ceftriaxone before surgery. Two SSI were classified as superficial incisional with isolated $\mathrm{C}$ aureus in one, and methicillin resistant staphylococcus aureus in another case, while one infection was classified as deep SSI - meningitis, without established etiology. SSI's were not noticed in patients who were treated with antibiotic prophylaxis with cefuroxime before surgery.
The following were the cases with postoperative SSI: One three year old male child (who underwent elective surgical intervention, with clean wound, functional, ACA2, duration of surgery of 2 hours and postoperative hospital stay of 9 days) with isolated $C$ aureus; one 62 year old male patient (who underwent urgent surgical intervention as a result of trauma, with ACA3, contaminated wound, duration of surgery of 2 hours, with comorbidity - cirrhosis, cardiovascular/CMP, hematological and neurological, with 28 days postoperative stay and fatal outcome) with isolated methicillin resistant staphylococcus aureus; and 64 year old female patient (who underwent elective surgical intervention as a result of tumor, with clean-contaminated wound - entry at frontal/ethmoidal sinus, with ACA3, duration of surgery of 6 hours, postoperative stay of 21 days, previously treated with corticosteroids and comorbidity - hematological/lymphoma, cardiovascular and neurologically) with meningitis, without isolated etiological liquor agent.

\section{DISCUSSION AND CONCLUSIONS}

The incidence of SSI in patients after neurosurgical intervention is between $1.25 \%$ and $17 \%$ in condition of prophylactic administration of antibiotics, and $0.3 \%$ to $3.0 \%$ without antibiotic prophylaxis $[2,12,4,13,14,31,32]$.

The suggested allowed range of annual SSI incidence is less than [15]. The SSI rate without antibiotics is between $5 \%$ and $11 \%$ in case of liquor shunts, between $1 \%$ and $5 \%$ in case of craniotomies and spinal surgeries in clean and clean-con- 
taminated interventions, and between $11 \%$ and $38 \%$ in case of liquor fistulas [31,31,33,34].

The risk is higher in case of craniotomies compared to spinal procedures [35], whereas, in clean neurosurgical procedures there had been SSI in $2.24 \%$ compared to $20 \%$ in case of contaminated [36]. Significant procedural risk factors for SSI are urgent as opposed to elective neurosurgical procedures, clean-contaminated and contaminated surgical interventions, ACA score 3, performing more than one procedure during the surgical intervention, as well as duration of the operative intervention more than 4 hours $[37,38,39,40]$.

After spinal neurosurgical procedures, important risk factors for occurrence of postoperative SSI are also posterior approach, tumor resection procedures and dural interruption [41]. Prolonged administration of antibiotics post operation is significantly associated with the incidence of postoperative SSI [35].

Further significant factors contributing to the incidence and increasing the risk of postoperative SSI after neurosurgical interventions are age extremes, diabetes, obesity, alcohol consumption, smoking, peripheral vascular disease, metastasized cancer, preoperative sepsis, administration of corticosteroids, prolonged hospitalization, surgical re-exploration, etc. [37,21,42], and also, in addition to the patient's specifics and the neurosurgical intervention, also important are the specifics related to the institution, operational room, skin preparation, disinfection, the experience of the surgeon, season, and many other [35].

Careful determination of all potential risk factors of postoperative SSI after neurosurgical procedures and their precise quantification and stratification is of high importance, not only related to the consequences for the patient and the institution (health and financial), but also, for the possibility of inter and intra-institutional comparison (the experience of the surgeon is also an important and measurable indicator), and the possibility of making adequate strategic decisions for undertaking specific preventive measures, especially because the benefit for the patient of such strategic approaches is inversely associated with the basic/primary risk of their occurrence [37].

Infections of operative wounds are mostly characterized with classical signs of redness (rubor), pain (dolor), swelling (tumor), increased temperature at the site of incision (calor) and systemic febrility [43]. Finally, the operative wound is filled with necrotic tissue, neutrophils, bacteria and fluids with protein content, altogether forming pus.
In addition to the significant scientific achievements related to the best practices and the progress of refining (improvements) of surgical techniques, the technological progress and improvements in the environment of ORs, as well as the application of prophylactic preoperative antibiotics, SSI remain to be second most frequent unwanted incidents in case of hospitalized patients, and the main source of morbidity after surgical procedures $[44,45]$. A study conducted by Duke University during 1999 shows that SSI double the risk of fatal outcome in patients, from $3.5 \%$ to $7.8 \%$, increase the probability for ICU treatment from $18 \%$ to $29 \%$, additional hospitalization of 5 days, double the costs for hospitalization from USD 3.844 to USD 7.531, and increase the probability for readmission (repeated hospitalization) from $7 \%$ to $41 \%$ [46].

There are numerous factors on the side of the patient (endogenous) and on the part of the processes/procedures (exogenous) which influence the risk in patient for incidence of postoperative infections. Some of these, for example, age and gender, cannot be changed or improved; however, most of the others, such as the nutritive status, smoking, adequate application of antibiotics or intraoperative techniques may be improved for positive outcomes from the operative intervention [47].

Primary sources of infection for most SSI are endogenous microorganisms of the patient. All patients without exceptions are colonized with bacteria, fungus and viruses - up to three million microorganisms per square centimeter of skin. Nevertheless, neither all patients, nor all microorganisms are created equal. Patients with history of diabetes, chronic obstructive lung disease, who need long-term treatment with corticosteroids or have other chronic diseases which require multiple hospitalization and/or patients treated with antibiotic therapy, are usually more colonized with bacteria, especially bacteria resistant to antibiotics, such as MRSA. All surgical wounds are contaminated during the surgical intervention, but only a small portion of them become infected (Fry DE, 2003), this is because defense mechanisms of the host in most of the patients are capable of controlling and eliminating responsible microorganisms in case when the inoculum of the wound is small, bacterial contaminants are not highly virulent, the microenvironment of the operative wound is "healthy" and the defense of the host is intact. There is a possibility for conceptual modelling, i.e. express the risk of SSI related to the patient's specifics with mathematical equation in 
order to reduce the SSI risk below one, i.e. result in absence of postoperative SSI, whereas, the risk of SSI equals the level of bacterial contamination multiplied by the virulence of microorganisms, altogether divided by the resistance of the patient to the infection. Regardless of the type of intervention, the patient's skin can never be sterile, however, there are many strategic approaches to reduce biological load.

The risk of SSI depends on many patient related factors, including preexistent medical conditions, the amount of the type of resistant bacteria on the skin, perioperative glycose concentrations, fluctuations of body temperature, as well as preoperative, intraoperative and postoperative care. Hence, it is clear that it would be very difficult to predict which operative wound would become infected. Therefore, it is necessary to identify in time the risk factors susceptible to variations, in order to minimize the risks of wound contamination in all cases undergoing surgical interventions, as well as to assist the defensive system in patients by continuous patient care.

Surgical site infections are persistent significant problem regardless of the prophylactic application of systemic antibiotics and improvements in the surgical techniques; however, there is decrease of their incidence [48].

Surgical wounds often include areas of local hematomas or seroma and tissue ischemia, which cannot be reached by systemically administered antibiotics (49.50)). Such unreachable areas are even more emphasized in patients after trauma, due to the extensive damage of the soft tissues [51].

Postoperative infections of the central nervous system after neurosurgical procedures, mainly presented as meningitis, epidural abscess, subdural empyema and/or brain abscess, pose a serious threat imposing the need of medical and/ or surgical intervention [52]. There is initial inflammation after the CNC infection in the choroid plexus, whereas, for the occurrence of postoperative infection of the central nervous system, the number of bacterial casers should be around $10^{5}$ per gram of tissue [53].

A study involving over 6200 performed craniotomies, showed CSF leak and male gender as independent risk factors for the incidence of postoperative $\mathrm{CNC}$. The role of antibiotic prophylaxis in context of the incidence of CNC postoperative infections after performed neurosurgical interventions has been investigated in many studies [52], which have presented that antibiotic prophylaxis reduces the incidence of postoperative infections of the central nervous system [54[. In studies involving at least 1000 intracranial neurosurgical procedures, the incidence of postoperative infections of the central nervous system after neurosurgical procedures had been $5 \%-7 \%$ but without antibiotic prophylaxis up to $10 \%[40,54,55,52]$. The study of over 2000 neurosurgical procedures in the USA, which analyzed postoperative infections of the central nervous system presented a significantly lower incidence of such infections, and suggested that almost half of them were associated with implants, but not CSF leak, diabetes or male gender, and suggested that in case of operative infections associated with high risk of infections, the primary care should be prophylaxis against $\mathrm{S}$ aureus and $\mathrm{P}$ acnes [52].

\section{REFERENCES}

1. Mangram AJ, Horan TC, Pearson ML, Silver LC, Jarwis WR: Guideline for prevention of surgical site infection, 1999. Centers for Disease Contyrol and Prevention (CDC) Hospital infection control practices advisory committee, Am J Infect Control 1999; 27:97-132

2. Jiang X, Ma J, Hou F, Li J, Li R, Lang H: Neurosurgical site infection prevention: Single institute experience, Turk Neurosurg 2016; 26(2):234-239

3. Inigo JJ, Bermejo B, Oronoz B, Herrera $\mathrm{J}$, Tarifa A, Perez F, Miranda C, Lera JM: Surgical site infection in general surgery: 5-yaer analysis and assessment of the National Nosocomial Infection Surveillance (NNIS) index, Cir Esp 2006; 79:224-230

4. Kasatpibal N, Norgaard M, Jamulitrat SW: Improving surveillance system and surgical site infection rates through a network: A pilot study from Thailand, Clin Epidemiol 2009; 1:67-74

5. Waits SA, Fritze D, Banerjee M, Zhang W, Kubus J, Englesbe MJ, Campbell DA Jr, Hendren S: Developing an argument for bundled interventions to reduce surgical site infection in colorectal surgery, Surgery 2014; 155:602606

6. Ward VP, Charlett A, Fagan J, Crawshaw SC: Enhanced surgical site infection surveillance following caesarean section: Experience of a multicenter collaborative post-discharge system, J Hosp Infect 2008; 70:166-173 
7. Gibbons C, Bruce J, Carpenter J, Wilson AP, Wilson J, Pearson A, Lamping DL, Krukowski ZH, Reeves BC: Identification of risk factors by systematic review and development of risk-adjusted models for surgical site infection, Health Technol Assess 2011; 15:1-156

8. Gaynes RP, Culver DH, Horan TC, Edwards JR, Richards C, Tolson JS: Surgical site infection (SSI) rates in the United States, 19921998: The National Nosocomial Infections Surveillance System basic SSI risk index, Clin Infect Dis 2001; 33(Suppl 2):S69-77

9. Haley RW, Culver DH, White JW, Morgan WM, Emori TG, Munn VP, Hooton TM: The efficacy of infection surveillance and control programs in in preventing nosocomial infections in US hospitals, Am J Epidemiol 1985; 121:182-205

10. Geubbels EL, Nagelkerke NJ, Mintjes-De Groot AJ, Vandenbroucke-Grauls CM, Grobbee DE, De Boer AS: Reduced riski of msurgical site infections through surveillance in a network, Int J Qual Health Care 2006; 18:127-133

11. Healey MA, Shackford SR, Osler TM, Rogers FB, Burns E: Complications in surgical patients, Arch Surg 2002; 137:611-617

12. Buang SS, Haspani MS: Risk factors for neurosurgical site infection after a neurosurgical procedure: A prospective observational study at Hospital Kuala Lumpur, Med J Malaysia 2012; 67(4):393-8

13. Kulkarni AV, Drake JM, Lamberti-Pasculli M: Cerebrospinal fluid shunt infection: A prospective study of risk factors, J Neurosurg 2001; 94(2):195-201

14. Valentini LG, Casali C, Chatenoud L, Chiaffarino F, Uberti-Foppa C, Broggi G: Surgical site infection after elective neurosurgery: A survey of 1747 patients, Neurosurgery 2009; 62(1):88-95

15. Haines SJ:: Efficacy of antibiotic prophylaxis in clean neurosurgical operations, Neurosurgery $1989 ; 24: 401-405$

16. Borges ES, Machado Ferreira SC: Relevant actions in the control of surgical site infections in neurosurgery: An integrative review, OBJN 2016; 15(4):1-9

17. World Health Organization (SWZ): WHO guidelines for safe surgery, 2009, Geneva:WHO

18. Owens CD, Stoessel K: Surgical site infections: epidemiology, microbiology and prevention, J Hosp Infect 2008; 70(S2):3-10
19. Edwards JR, Peterson BBA, Banerjee S, Allen-Bridson K, Morrell G, Margaret A: National Health Safety Network (NHSN) Report, data summary for 2006 through 2007, Am J Infect Control 2008; 36:609-26

20. Schweizer ML, Cullen JJ, Perencevich EN, Vaughan Sarrazin MS: Costs associated with surgical site infections in Veterans affairs hospitals, JAMA Surg 2014; 149(6):575-81

21. Kaye KS, Schmit K, Pieper C, Sloane R, Caughlan KF, Sexton DJ, Schmader KE: The effect of increasing age on the risk factor of surgical site infection, J Infect Dis 2005; 191:1056-62

22. Cruse PJ: Wound infection surveillance, Rev Infect Dis 1981; 4(3):734-47

23. Vegas AA, Garcia ML: Nosocomial infection in surgery wards: A controlled study of increased duration of hospital stays and direct cost of hospitalization, Eur J Epidemiol 1993; 9(5):504-10.

24. Nishant, Kailash KK, Vijayraghavan PV: Prospective randomized study for antibiotic prophilaxis in spine surgery: Choice of drug, dosage and timing, Asian Spine J 2013; 7(3):196-203

25. Holloway KL, Smith KW, Wilberger J, Collins JJ: Antibiotic prophylaxis during clean neurosusrgery: A large, multicenter study using cefuroxime, Clin Ther 1996; 18(1):84-94

26. Malomo AO, Adeolu AA, Odebode TO, Komolafe EO, Shokunbi MT: Prospective comparative trial of ceftriaxone versus ceftazidime as prophylactic perioperative antimicrobials in neurosurgery, ECA J Surg 2007; 12(1):89-92

27. Zhao JZ, Wang S, Li JS, Yang J, Zang JT, He Q, Shao LL, Dai ZX, Chao XY, Lau KC: The perioperative use of ceftriaxone as infection prophylaxis in neurosurgery, Clin Neurol Neurosurg 1995; 97(4):285-9

28. Zhu XL, Wong WK, Yeung WM, Mo P, Tsang CS, Pang KH, Po YC, Aung TH: A randomized, double-blind comparison of ampicillin/ sulbactam and ceftriaxone in the prevention of surgical-site infections after neurosurgery, Clin Ther 2001; 23(8):1281-91

29. Arnaboldi L: Antimicrobial prophylaxis with ceftriaxone in neurosurgical procedures, Chemother 1996; 42(5):384-390

30. Bodzinski J, Barczewska M, Marchel A: Ceftriaxone in short-term program of perioperational prophylaxis in neurosurgery, Neurol Neurochir Pol 1993; 27(1):55-61 
31. Barker II FG: Efficacy of prophylactic antibiotic for craniotomy: A meta-analysis, Neurosurgery 1994; 35(3):484-92

32. Bullock R, van Dellen JR, Ketelbey W: A double-blind placebo-controlled trial of perioperative prophylactic antibiotics for elective neurosurgery, J Neurosurg 1988; 69(5):687-91

33. Dempsey R, Rapp RP, Young B: Prophylactic parenteral antibiotics in clean neurosurgical procedures: A review, J Neurosurg 1988; 69:52-7

34. Djindjian M: Antibiotic prophylaxis in neurosurgery, Ann Fr Anesth Reanim 1994; 13:93-5

35. Petrica $A$, Ionac $M$, Brinzeu $C$, Brinzeu A: Surgical site infections surveillance in neurosurgery patients, Tim Med J 2009; 3-4:1-4

36. Altemeier WA: Sepsis in neurosurgery. Presidential address, Arch Surg 1982; 117(2):107-12

37. Van Walraven C, Musselman R: The surgical site infection risk score (SSIRS): A model to predict the risk of surgical site infections, PLOS ONE 2013; 8(6):1-4

38. Bowater RJ, Stirling SA, Lilford RJ: Is antibiotic prophylaxis in surgery a generally effective intervention? Testing a generic hypothesis over a set of meta-analyses, Ann Surg 2009; 249:551-6

39. Gibbons C, Bruce J, Carpenter J, Wilson AP, Wilson J: Identification of risk factors by systematic review and development of risk-adjusted models for surgical site infection, Health Technol Assess 2011; 15:1-iv

40. Korinek AM: Risk factors for neurosurgical site infections after craniotomy: A prospective multicenter study of 2944 patients. The French study group of neurosurgical infections, the SEHP, and the C-CLIN Paris-Nord service epidemiologie hygiene et prevention. Neurosurgery 1997; 41(5):1073-81

41. Margaret AO, Jennie M, Carl L: Risk factors for surgical site infection in spinal surgery, J Neurosurg (Spine 2) 2003; 98:149-55

42. Heymsfield SB, Wadden TA: Mechanisms, pathophysiology and management of obesity, N Engl J Med 2017; 376(3):254-66

43. Fry DE: Surgical site infection: Pathogenesis and prevention. CME Program. Medscape from WebMD 2003

44. Leape LL, Brennan TA, Laird N: The nature of adverse events in hospitalized patients. Results of the Harvard Medical Practice Study II. N Engl J Med 1991; 324 (6):377-384
45. Nathens AB, Cook CH, Machiedo G, Moore EE, Namias N, Nwariaku F: Defining the research agenda for surgical infection: A consensus of experts using the Delphi approach. Surg Infect 2006; 7(2):101-110

46. Kirkland KB, Briggs JP, Trivette SL, Wilkinson WE, Sexton DJ: The impact of surgical-site infections in the 1990s: Attributable mortality, excess length of hospitalization, and extra costs. Infect Control Hosp Epidemiol 1999; 20(11):725-730

47. Barnard B: Prevention of surgical site infections. Infect Control Today 2003; 71(4):57-60

48. Savitz MH, Katz SS: Rationale for prophylactic antibiotics and neurosurgery. Neurosurgery $1981 ; 9: 142-4$

49. Stall AC, Becker E, Ludwig SC et al.: Reduction of postoperative spinal implant infection using gentamicin microspheres, Spine 2009; 34(5):479-83

50. Hanssen AD, Osmon DR, Patel R: Local antibiotic delivery systems: Where are we and where are we going? Clin Orthop Relat Res 2005; 437:111-4

51. O'Neill KR, Smith JG, Abtahi AM, Archer KR, Spengler DM, McGirt MJ, Devin CJ: Reduced surgical site infections in patients undergoing posterior spinal stabilization of traumatic injuries using vancomycin powder, Spine J 2011; 11:641-646

52. McClelland III S, Hall W: Postoperative central nervous system infection: Incidence and associated factors in 2111 neurosurgical procedures, CID 2007; 45:55-9

53. Borges LF: Infections in neurologic suregery: Host defenses, Neurosurg Clin N Am 1992; $3: 275-8$

54. Korinek AM, Baugnon T, Golmard JL, van Effenterre R, Coriat P, Puybasset L: Risk factors for adult nosocomial meningitis after craniotomy: Role of antibiotic prophylaxis, Neurosurgery 2006; 59:126-33

55. Mollman HD, Haines SJ: Risk factors for postoperative neurosurgical wound infection: A case-control study, J Neurosurg 1986; 64:902-6 


\title{
ЗНАЧЕЊЕТО НА ПЕРИОПЕРАТИВНАТА ПРОФИЛАКСА СО ЦЕФУРОКСИМ ИЛИ ЦЕФТРИАКСОН ВО ПРЕВЕНЦИЈА НА ИНФЕКЦИИ НА ОПЕРАТИВНОТО ПОЛЕ ПО КРАНИЈАЛНИ И СПИНАЛНИ НЕВРОХИРУРШКИ ПРОЦЕДУРИ
}

\author{
Александра Гавриловска-Димовска ${ }^{1}$, Александар Чапароски ${ }^{1}$, Андреја Гавриловски르, Звонко Миленковиќ ${ }^{3}$ \\ ${ }^{1}$ Универзитетска клиника за неврохирургија, Водњанска 17, 1000, Скопје, Република Македонија \\ 2 Универзитетска клиника за трауматологија, Водњанска 17, 1000, Скопје, Република Македонија \\ ${ }^{3}$ Универзитетска клиника за инфективни болести, Водњанска 17, 1000, Скопје, Република Македонија
}

\section{Резиме}

\section{Вовед}

Инфекциите на оперативното поле претставуваат значаен проблем во третманот при неврохиоруршките оперативни процедури и покрај примената на периоперативна профилакса со системски антибиотици. Стапката на инфекции кај овие процедури изнесува од помалку од $1 \%$ до над $15 \%$ \%. Во периоперативната профилакса досега се користени различни антибиотици и различни режими на администрација, постојат бројни споредбени студии за нивната ефикасност, но генерално се посочува дека изборот на истите би требало да базира врз сознанијата и локалните специфики поврзани со најверојатните бактериски причинители за којшто се очекува евентуална контаминација на оперативното поле и можноста тие да предизвикаат инфекција, како и, клучно, задолжителното придржување кон принципите за обезбедување на соодветни концентрации на лекот локално во моментот на очекуваната контаминација.

\section{Цел}

Да се компарира протективниот ефект на два периоперативни профилактички антибиотски режими со цефуроксим (цефалоспорин од втора генерација) и цефтриаксон (цефалоспорин од трета генерација) во превенција на постоперативни инфекции на оперативното поле по извршени елективни и ургентни кранијални и спинални неврохируршки процедури на Универзитетската клиника за неврохирургија во Скопје во текот на првите три месеци од 2016 г.

\section{Дизајн на студијата}

Проспективна рандомизирана компаративна студија.

\section{Мерки на исходот}

Определување на клиничкиот исход претставен како застапеност на суперфицијалните и длабоките инцизионални и орган/простор постоперативни инфекции на оперативното поле.

\section{Материјал и методи}

Проспективно се анализирани 40 пациенти кај којшто пред рутинските неврохируршки кранијални и спинални оперативни процедури еден час пред операцијата е админиострирана парентерална антибиотска профилакса со два антибиотски режими, рандомизирани во две групи, по редоследот на доаѓањето и вклучувањето во студијата, наизменично, неселективно, лицата којшто ги исполнуваа инклузионите критериуми беа поставувани на еден од двата програмирани режими со цефуроксим во првата, односно, цефотаксим во втората компарирана група. Анализирани се сите релевантни демографски и периоперативни податоци за пациентите во двете компарирани групи и особено факторите за кои е познато дека создаваат диспозиција (предиспонираат) кон инфекции. Како примарен исход е евалуирана застапеноста на постоперативните инфекции во двете компарирани групи, додека како секундарни, вкупната стапка на постоперативни инфекции по спроведени кранијални и спинални неврохируршки оперативни процедури на Клиниката за неврохирургиоја во Скопје (со оглед дека досега нема објавени податоци за истите), како и застапеноста на факторите на ризик за појава на постоперативни инфекции предоперативно кај лицата кои подлежат на неврохируршки интервенции локално во Република Македонија. 


\section{Резултати}

Вкупно се регистрирани три случаи со постоперативни инфекции, од кои во два случаја тие беа класифицирани како суперфицијални инцизионални, додека во еден, инфекција на орган/простор - менингитис (елективна интервенција) без етиолошка потврда. Двете компарирани групи беа статистички слични, без статистички значајни разлики во базичните демографски и периоперативни карактеристики, како и, особено, во однос на застапеноста на факторите кои независно од антибиотската профилакса предиспонираат кон постоперативни инфекции. Сите три случаи со инфекции се регистрирани во групата лица кои периоперативно примиле профилакса со цефтриаксон, со изолиран етиолошки агенс S aureus (елективна интервенција) во еден и метицилин резистентен стафилококус aypeyc (MRSA) во другиот случај (ургентна интервенција) со суперфицијални инцизијални ИОП. Во групата пациенти кои периоперативно примале цефуроксим не е регистриран ниту еден случај на ИОП.

\section{Заклучок}

Примената на парентерални антибиотици периоперативно ја намалува инциденцата на постоперативните инфекции по извршените неврохируршки оперативни процедури, особено кај случаите со присутни фактори на зголемен ризик за појава на ИОП како што се АСА скор $\geq 2 / 3$, времетраење на оперативната интервенција $\geq 4$ часа, контаминирана рана и коморбидности. Периоперативната антибиотска профилакса треба да биде насочена кон подобро покривање на соевите на S.aureus.

Клучни зборови: Инфекции на оперативно поле, Неврохирургија, Антибиотска профилакса, Цефуроксим, Цефтриаксон 